\title{
Salinomycin induces selective cytotoxicity to MCF-7 mammosphere cells through targeting the Hedgehog signaling pathway
}

\author{
YING-ZI FU ${ }^{1 *}$, YUAN-YUAN YAN ${ }^{1 *}$, MIAO HE ${ }^{1}$, QING-HUAN XIAO ${ }^{1}$, WEI-FAN YAO ${ }^{1}$, LIN ZHAO ${ }^{1}$, \\ HUI-ZHE WU ${ }^{1}$, ZHAO-JIN YU ${ }^{1}$, MING-YI ZHOU ${ }^{1}$, MU-TIAN LV ${ }^{1}$, \\ SHAN-SHAN ZHANG ${ }^{1}$, JIAN-JUN CHEN ${ }^{2}$ and MIN-JIE WEI ${ }^{1}$ \\ ${ }^{1}$ Department of Pharmacology, School of Pharmacy, China Medical University, Shenyang, Liaoning 110122, P.R. China;
}

Received August 12, 2015; Accepted September 26, 2015

DOI: 10.3892/or.2015.4434

\begin{abstract}
Breast cancer stem cells (BCSCs) are believed to be responsible for tumor chemoresistance, recurrence, and metastasis formation. Salinomycin (SAL), a carboxylic polyether ionophore, has been reported to act as a selective breast CSC inhibitor. However, the molecular mechanisms underlying SAL-induced cytotoxicity on BCSCs remain unclear. The Hedgehog $(\mathrm{Hh})$ signaling pathway plays an important role in CSC maintenance and carcinogenesis. Here, we investigated whether SAL induces cytotoxicity on BCSCs through targeting Hh pathway. In the present study, we cultured breast cancer MCF-7 cells in suspension in serum-free medium to obtain breast CSC-enriched MCF-7 mammospheres (MCF-7 MS). MCF-7 MS cells possessed typical BCSC properties, such as $\mathrm{CD} 44^{+} \mathrm{CD} 24^{-/ \text {low }}$ phenotype, high expression of OCT4 (a stem cell marker), increased colony-forming ability, strong migration and invasion capabilities, differentiation potential, and strong tumorigenicity in xenografted mice. SAL exhibited selective cytotoxicity to MCF-7 MS cells relative to MCF-7 cells. The Hh pathway was highly activated in BCSC-enriched MCF-7 MS cells and SAL inhibited Hh signaling activation by downregulating the expression of critical components of the Hh pathway such as PTCH, SMO, Gli1, and Gli2, and subsequently repressing the expression of their essential downstream targets including C-myc, Bcl-2, and Snail (but not cyclin D1). Conversely, Shh-induced Hh signaling activation could largely reverse SAL-mediated inhibitory effects. These
\end{abstract}

Correspondence to: Dr Min-Jie Wei, Department of Pharmacology, School of Pharmacy, China Medical University, 77 Puhe Road, Shenyang North New Area, Shenyang, Liaoning 110122, P.R. China E-mail: weiminjiecmu@163.com

\section{${ }^{*}$ Contributed equally}

Key words: Hedgehog signaling pathway, MCF-7 mammospheres, breast cancer stem cells, salinomycin, cytotoxicity findings suggest that SAL-induced selective cytotoxicity against MCF-7 MS cells is associated with the inhibition of $\mathrm{Hh}$ signaling activation and the expression of downstream targets and the Hh pathway is an important player and a possible drug target in the pathogenesis of BCSCs.

\section{Introduction}

Breast cancer is one of the most common malignant cancers worldwide, and is the leading cause of cancer-related death in women (1). Despite great advances in the treatment of breast cancer in recent years, the development of drug resistance and relapse is a major hurdle in the treatment of breast cancer (2). Recent studies have shown that cancer stem cells (CSCs), a rare subpopulation of cells with tumorigenic potential, are resistant to chemotherapy, thereby allowing tumor regrowth (3-5). Therefore, targeting chemotherapy-resistant breast CSCs will be essential to prevent breast cancer resistance and relapse.

The Hedgehog (Hh), Notch, and Wnt signaling pathways are crucial to cell proliferation, apoptosis, and differentiation during embryonic development, and play an important role in CSC maintenance and carcinogenesis (6-8). Recently, the Hh signaling pathway has attracted extensive attention in the CSC research. Aberrant activation of the Hh pathway has been found in many tumors, such as gastric carcinoma, pancreatic cancer, esophageal carcinoma, and small-cell lung cancer (9-12). In addition, it has been reported that $\mathrm{Hh}$ signaling activation is required for human glioma growth and survival as well as CSC self-renewal and tumorigenicity (13). Tanaka et al reported that the Hh signaling pathway played an essential role in maintaining the highly tumorigenic populations of breast cancer cells, including the side population and the $\mathrm{CD} 44^{+} \mathrm{CD} 24^{-/ \text {low }}$ subpopulation (14). Therefore, targeting Hh signaling pathway represents a novel and promising therapeutic strategy for the treatment of breast cancer. Currently, Hh pathway inhibitors are undergoing preclinical and clinical studies as anticancer agents (15).

Salinomycin (SAL), a carboxylic polyether ionophore, has recently been identified as a highly effective inhibitor of breast CSCs by high-throughput screening (16). Subsequently, SAL 
has been shown to selectively kill CSCs in many other cancers including colorectal cancer, gastric cancer, pancreatic cancer, head and neck squamous cell carcinoma, and endometrial cancer (17-21). Nevertheless, the mechanisms underlying selective toxicity of SAL for CSCs remain poorly understood. It has been reported that SAL inhibits cancer cell growth and migration by promoting oxidative stress, and inducing apoptosis and autophagy (22-26). In addition, Lu et al reported that SAL inhibited the Wnt signaling pathway and selectively induced cell apoptosis in chronic lymphocytic leukemia cells (27). SAL has been reported to selectively inhibit osteosarcoma stem cells and downregulate Wnt signaling (28). However, it remains unclear whether the Hh signaling pathway is involved in SAL-induced toxicity for breast CSCs.

In the present study, we cultured breast cancer MCF-7 cells in suspension in serum-free medium to obtain BCSC-enriched MCF-7 mammospheres (MCF-7 MS), and examined the effect of SAL on proliferation, apoptosis, migration and invasion of MCF-7 MS cells. More importantly, we investigated the role/involvement of the Hh signaling pathway in SAL-induced selective cytotoxicity against MCF-7 MS cells. Our study showed that the Hh signaling pathway was highly activated in BCSC-enriched MCF-7 MS. The inhibition of the Hh signaling pathway mediated by SAL was critical for SAL-induced selective cytotoxicity to breast CSCs.

\section{Materials and methods}

Cell culture and mammosphere generation. The human breast cancer MCF-7 cell line was purchased from the American Type Culture Collection (ATCC; Manassas, VA, USA). The cells were maintained in Dulbecco's modified Eagle's medium (DMEM; Invitrogen, USA) containing 10\% fetal bovine serum (Hyclone, USA), $100 \mathrm{U} / \mathrm{ml}$ penicillin, and $100 \mathrm{mg} / \mathrm{ml}$ streptomycin in a humidified atmosphere with $5 \% \mathrm{CO}_{2}$ at $37^{\circ} \mathrm{C}$. Mammospheres were cultured as previously reported by Ponti et al (29). Briefly, MCF-7 cells $\left(5 \times 10^{4} / \mathrm{ml}\right)$ were cultured in suspension in serum-free DMEM-F12 (Gibco, USA), supplemented with 2\% B27 (Invitrogen) and $20 \mathrm{ng} / \mathrm{ml}$ EGF and $10 \mathrm{ng} / \mathrm{ml} \mathrm{bFGF}$ (both from Peprotech, USA). Cells were grown in these conditions as non-adherent spherical clusters of cells, the MCF-7 mammospheres (MCF-7 MS). MCF-7 MS cells were enzymatically dissociated every 5-6 days with $0.25 \%$ trypsin and subcultured in DMEM-F12 with growth factors as described above.

Flow cytometric analysis. Flow cytometry was performed to determine the expression of CD44 and CD24 in MCF-7 and MCF-7 MS cells, apoptosis, and cell cycle change in the SAL-treated MCF-7 MS cells. For analysis of CD44 and CD24 expression, cells were suspended at a density of $1 \times 10^{6}$ cells $/ \mathrm{ml}$ in $100 \mu \mathrm{l}$ PBS and incubated with fluorescence isothiocyanate (FITC)-conjugated antibodies against CD44 (1:20) and phycoerythrin (PE)-conjugated antibodies against CD24 (1:10) (both from BD Pharmingen, USA) for $30 \mathrm{~min}$ at $4^{\circ} \mathrm{C}$ in the dark. The cells were washed in PBS and centrifuged at $800 \mathrm{x} \mathrm{g}$ for $5 \mathrm{~min}$. Single-cell suspensions were analyzed by flow cytometry using FACSCalibur (Becton-Dickinson).

MCF-7 MS cells were treated with 30 and $60 \mathrm{nM} \mathrm{SAL}$ for $48 \mathrm{~h}$. DMSO was used as a negative control. Cells were the harvested by centrifugation, and washed twice with cold PBS. For apoptosis analysis, cells were resuspended in $250 \mu \mathrm{l}$ Annexin $\mathrm{V}$ binding buffer at a density of $1 \times 10^{6}$ cells $/ \mathrm{ml}$. The suspension $(100 \mu \mathrm{l})$ was incubated in the dark at room temperature for $15 \mathrm{~min}$ with a solution of Annexin V-FITC $(2.5 \mu \mathrm{g} / \mathrm{ml})$ and PI $(5 \mu \mathrm{g} / \mathrm{ml})$. Cells were analyzed for apoptosis by flow cytometer. For cell cycle analysis, cells were fixed with $70 \%$ ethanol and stored at $4^{\circ} \mathrm{C}$ overnight. Cells were then rehydrated with PBS for $10 \mathrm{~min}$, and stained with propidium iodide (PI, $50 \mu \mathrm{g} / \mathrm{ml}$ ) for $15 \mathrm{~min}$ at $37^{\circ} \mathrm{C}$ in PBS containing $2 \mu \mathrm{g} / \mathrm{ml}$ RNase A and $0.2 \%$ NP-40. Cell cycle analysis was performed by flow cytometry.

Soft agar colony formation assay. MCF-7 and MCF-7 MS cells $\left(10^{3}\right.$ cells $\left./ \mathrm{ml}\right)$ were suspended in $0.6 \%$ agar with culture medium (1:1), and layered on preformed $1.2 \%$ agar with culture medium (1:1) base layer. Culture medium was added on the top agar layer every 3-4 days. After incubation for 3 weeks at $37^{\circ} \mathrm{C}$, the colonies/well was counted from 8 different random fields under an inverted microscope (Nikon TE2000-U; Nikon Japan).

Cell Counting Kit-8 (CCK-8/WST-8) assay. Cell viability was measured by a Cell Counting Kit-8 (CCK-8; Dojindo, Japan). MCF-7 or MCF-7 MS cells (8,000 cells/well) were seeded into 96-well ultra-low adherent plates (Corning, Lowell, MA, USA), and allowed to grow in the growth medium for $24 \mathrm{~h}$. To determine the $\mathrm{IC}_{50}$ value of SAL, cells were treated with various concentrations of SAL $(10,30,100$, 300, 1,000, 3,000 and 10,000 nM; Sigma, USA) for $48 \mathrm{~h}$. To investigate the effect of Shh on SAL-induced inhibition on MCF-7 MS proliferation, MCF-7 MS cells were treated with SAL (60 nM), Shh (3 $\mu \mathrm{g} / \mathrm{ml}$; R\&D Systems, Minneapolis, MN, USA), SAL $(60 \mathrm{nM})+\operatorname{Shh}(3 \mu \mathrm{g} / \mathrm{ml})$, or vehicle control (DMSO) for $48 \mathrm{~h}$. Cells in each well were then incubated with WST-8 (2-(2-methoxy-4-nitrophenyl)-3-(4-nitrophenyl)-5(2,4-disulfophenyl)-2H-tetrazolium) for $4 \mathrm{~h}$. Plates were read at $450 \mathrm{~nm}$ wavelength in an Anthos 2010 microplate reader (Anthos Labtec Instruments GmbH, Austria).

Transwell migration and invasion assays. Transwell migration and invasion assays were conducted as described by Fan et al (30). Briefly, the upper chambers were plated with $4 \times 10^{4} \mathrm{MCF}-7$ cells in $0.5 \mathrm{ml}$ serum-free DMEM medium or $4 \times 10^{4}$ MCF-7 MS cells in $0.5 \mathrm{ml}$ serum-free DMEM/F12 medium. The lower chambers were filled with $0.5 \mathrm{ml}$ cell culture medium containing $10 \%$ FBS. To test the effect of SAL on migration and invasion of MCF-7 MS cells, MCF-7 MS cells were pretreated with 30 and $60 \mathrm{nM} \mathrm{SAL}$, or vehicle control (DMSO) for $48 \mathrm{~h}$. Cells were allowed to migrate toward the lower chamber for $24 \mathrm{~h}$ at $37^{\circ} \mathrm{C}$. The number of cells migrating through the membrane was counted under a light microscope (x200 magnification, five random fields per well), and were analyzed using ImageJ software.

Total and nuclear proteins extraction and western blot analysis. Cells were harvested and total proteins were extracted was carried out as previously described (31), and nuclear proteins were extracted according to the manufacturer's protocol from nuclear protein extraction kit (Pierce 
Biotechnology, Rockford, IL, USA). Proteins were resolved by SDS-PAGE, and transferred onto polyvinylidene fluoride membranes by electroblotting. Membranes were blocked with 5\% milk in Tris-buffered saline with $0.1 \%$ Tween-20, and then incubated with primary antibodies against OCT4 (1:1,000; Cell Signaling Technology), Gli1 (1:500), Gli2 (1:800), PTCH $(1: 1,000)$ and SMO $(1: 1,000)$ (all from Abcam), C-myc $(1: 1,000)$ and Bcl-2 $(1: 1,000)$ (both from Cell Signaling Technology), cyclin D1 (1:1,000; Beyotime Biotechnology), Snail (1:300; Abcam), GAPDH (1:6,000; Santa Cruz Biotechnology) and histone H3 (1:1,000; Beyotime Biotechnology) overnight at $4^{\circ} \mathrm{C}$. Membranes were then incubated with horseradish peroxidase-conjugated goat anti-rabbit or goat anti-mouse secondary antibodies (dilution 1:5,000; Abcam) at room temperature for $1 \mathrm{~h}$. Bands were visualized using an enhanced chemiluminescence detection system (Amersham, Freiburg, Germany). The results were quantitatively analyzed using Scion Image software (Scion Corporation, Frederick, MA, USA).

Mammosphere formation assay. Single-cell suspensions of MCF-7 MS cells were thoroughly suspended and plated in 6-well ultra-low adherent plates (Corning) at $1 \times 10^{5}$ cells/well in $4 \mathrm{ml}$ of sphere formation medium. After $24 \mathrm{~h}$, cells were treated with SAL, Shh, or DMSO as a control for $48 \mathrm{~h}$. Cells were then collected, digested into single cells and plated in 6 -well ultra-low adherent plates with 2,000 cells/well in mammosphere formation medium $(2 \mathrm{ml})$. Fresh medium $(1 \mathrm{ml})$ was added into the plates every 3-4 days. After culture for 8 days, the number of the mammospheres $/ 2,000$ cells was counted for the primary mammosphere formation assay under an inverted microscope (Nikon TE2000-U; Nikon). The above mammospheres in each group were collected, digested into single cells and plated in 6-well ultra-low adherent plates with 2,000 cells/well in mammosphere formation medium $(2 \mathrm{ml})$ for the secondary mammosphere formation assay.

Immunofluorescence. MCF-7 MS cells were treated with 30 and $60 \mathrm{nM} \mathrm{SAL}$, or DMSO as a control for $48 \mathrm{~h}$. After the treatment, cells were collected and rinsed in PBS before incubation in 4\% paraformaldehyde for $30 \mathrm{~min}$ and embedded in paraffin wax. Sections $(4 \mu \mathrm{m})$ were cut and subjected to immunofluorescence staining. Cells were permeabilized with $0.5 \%$ Triton X-100 (Sigma) for $10 \mathrm{~min}$, rinse in PBS, and blocked with normal goat serum for $1 \mathrm{~h}$ at room temperature. The sections were incubated overnight at $4^{\circ} \mathrm{C}$ with primary antibodies against PTCH (1:20), SMO (1:100), Gli1 (1:100) and Gli2 (1:100) (all from Abcam). After primary antibody was removed by washing in PBS, immunoreactivity was detected by incubation with FITC-conjugated secondary antibodies (1:300; Invitrogen) for $1 \mathrm{~h}$ at room temperature. Nuclei were counterstained using DAPI for $15 \mathrm{~min}$. Fluorescence was detected using a Nikon Eclipse 80i microscope (Japan).

In vivo xenograft experiments. For the study of the tumorigenic ability of MCF-7 and MCF-7 MS cells, equal numbers of MCF-7 cells or MCF-7 MS cells $\left(2 \times 10^{3}, 2 \times 10^{4}, 2 \times 10^{5}\right.$ and $2 \times 10^{6}$ cells) were suspended in PBS and Matrigel (1:1; BD Biosciences), and subcutaneously inoculated into the flank of female BALB/c athymic nude mice ( $\mathrm{n}=6$ mice per group). The presence or absence of a visible or palpable tumor was evaluated 6 weeks after the initial injection of the cells. Mice ( $\mathrm{n}=5$ mice per group) inoculated with $2 \times 10^{6}$ MCF-7 or MCF-7 MS cells were sacrificed 6 weeks after the initial injection of the cells, and tumors were weighed and harvested for subsequent western blot analysis. All mice were bred in pathogen-free conditions at the Animal Center of China Medical University. All animal studies were carried out in accordance with the National Institute of Health Guide for the Care and Use of Laboratory Animals.

Statistical analysis. Statistical analyses were performed using the SPSS statistics 16.0 software package. Data are presented as mean \pm standard deviation (SD). Student's t-test was used to compare differences between two groups. One-way analysis of variance (ANOVA) was used to compare differences among more than two groups. Statistical significance was considered at $\mathrm{P}<0.05$.

\section{Results}

MCF-7 MS cells possess breast CSC-like properties. MCF-7 cells cultured in suspension in serum-free DMEM/F12 medium supplemented with growth factors formed tight sphere-like mammospheres after 7-8 passages (Fig. 1A). It has been shown that breast CSCs have a CD $44^{+} \mathrm{CD} 24^{-}$phenotype (32), so that we examined the presence of CD44 and CD24 in MCF-7 MS cells using flow cytometry. We found that the proportion of $\mathrm{CD} 44^{+} \mathrm{CD} 24^{-}$cells in MCF-7 MS cells was as high as $81.4 \pm 11.7 \%,>30$-fold greater than that $(2.53 \pm 1.28 \%)$ in the parental MCF-7 cells (Fig. 1B), indicating that MCF-7 MS cells expressed breast CSC-specific markers.

We next assessed the expression of the stem cell marker OCT4 in MCF-7 MS cells. Western blot analysis showed that the expression of OCT4 was significantly higher in MCF-7 MS cells compared with MCF-7 cells (Fig. 1C). Furthermore, we measured the colony-forming ability of MCF-7 MS cells, using soft agar colony formation assay. The MCF-7 MS cells formed significantly more colonies than MCF-7 cells (Fig. 1D). These data suggested that MCF-7 MS cells exhibited breast CSC-like self-renewal capacity.

We further investigated the migration and invasion capacity of MCF-7 MS cells, using Transwell migration and invasion assays. The number of MCF-7 MS cells that migrated and invaded into the lower Transwell chamber was significantly greater than that of MCF-7 cells (Fig. 1E), suggesting that MCF-7 MS cells exhibited increased migration and invasion.

We also examined the re-differentiation potential of the MCF-7 MS cells by culturing MCF-7 MS in DMEM culture medium with $10 \%$ FBS. After culture for $42 \mathrm{~h}$, some spherical MCF-7 MS cells began to grow adherently, and exhibited differentiation properties. After culture for $100 \mathrm{~h}$, MCF-7 MS cells completely lost the spheroid characteristics, grew adherently, and exhibited morphology similar to MCF-7 cells (Fig. 1F). The finding that MCF-7 MS cells could re-differentiate into MCF-7 cells under serum-rich conditions suggested that MCF-7 MS cells have the CSC-like differentiation potential.

To further investigate the in vivo tumorigenic ability of MCF-7 MS, we subcutaneously inoculated MCF-7 MS cells 
A
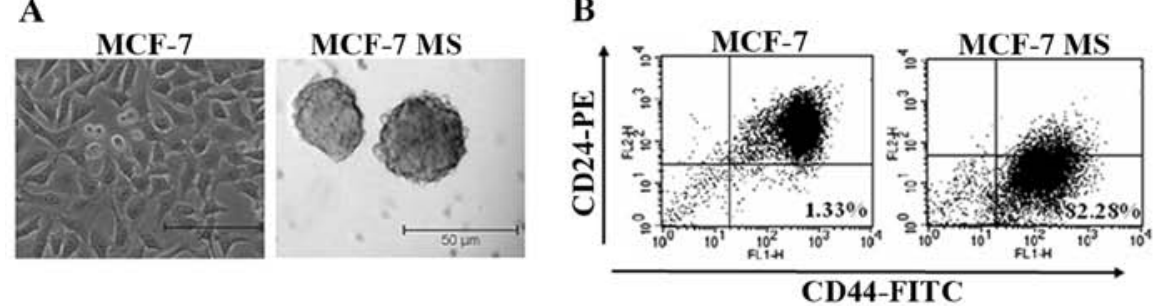

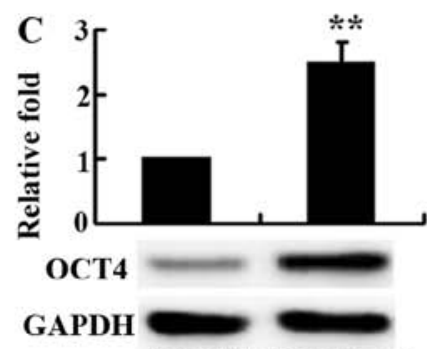

MCF-7 MCF-7 MS

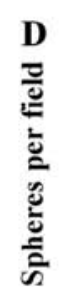

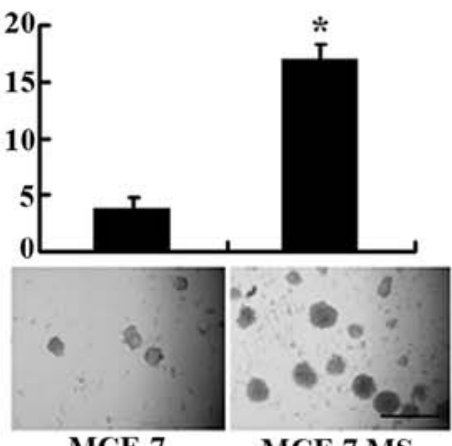

MCF-7
MCF-7 MS

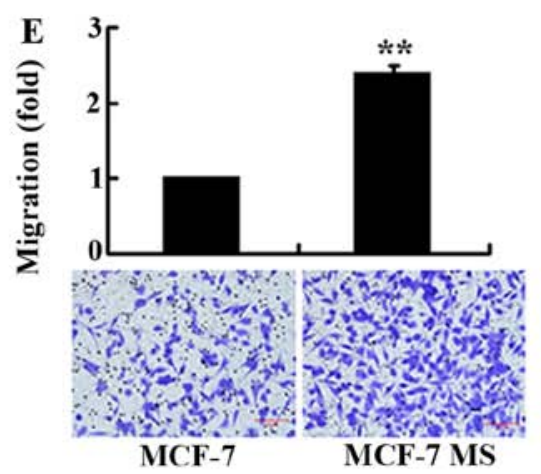

MCF-7

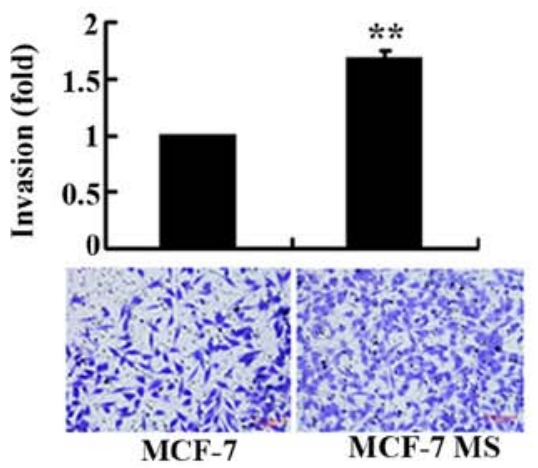

F

$\mathbf{0 ~ h}$

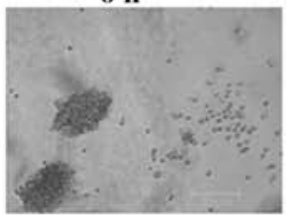

$42 \mathrm{~h}$

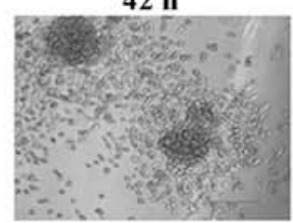

54 h

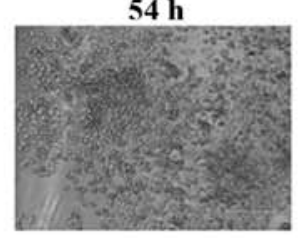

$70 \mathrm{~h}$

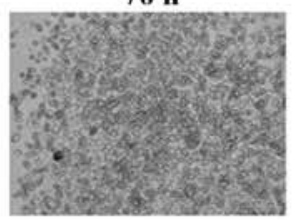

$100 \mathrm{~h}$

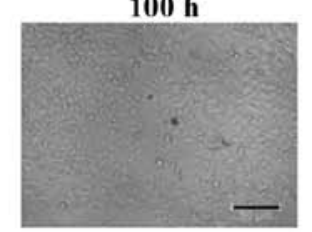

Figure 1. MCF-7 MS cells possess breast CSC-like properties. (A) MCF-7 cells were cultured in suspension in serum-free DMEM/F12 medium supplemented with $2 \% \mathrm{~B} 27,20 \mu \mathrm{g} / 1$ human EGF, and $10 \mu \mathrm{g} / 1$ human bFGF, and formed tight sphere-like mammospheres after 7-8 passages (scale bar, $50 \mu \mathrm{m}$ ). (B) Flow cytometry showing the percentage of CD44 ${ }^{+} \mathrm{CD} 24^{- \text {-low }}$ cells in MCF-7 and MCF-7 MS cells. (C) Western blot analysis showing the expression level of OCT4, a stem cell marker. GAPDH is a loading control. The expression level of OCT4 was normalized to that of GAPDH. The OCT4/GAPDH ratio in MCF-7 cells was set as 1. (D) MCF-7 MS cells exhibited increased colony-forming ability. MCF-7 cells and MCF-7 MS were grown in soft agar as described in the Materials and methods. The colony numbers were counted manually under a microscope after culture for 7 days (scale bar, $50 \mu \mathrm{m}$ ). (E) Transwell migration and invasion assays showing MCF-7 MS cells enhanced the ability of migration and invasion. Cells that migrated or invaded into the lower Transwell chambers were counted (scale bar, $20 \mu \mathrm{m}$ ). The number of MCF-7 cells migrating or invading to the lower chambers was set as 1. (F) MCF-7 MS cells were cultured in DMEM medium with $10 \% \mathrm{FBS}$ for 0 to $100 \mathrm{~h}$ (scale bar, $50 \mu \mathrm{m}$ ). Data are presented as mean \pm standard deviation (SD) from there independent experiments. ${ }^{*} \mathrm{P}<0.05$, ${ }^{* *} \mathrm{P}<0.01$ vs. MCF-7 cells.

or MCF-7 cells into the flank of nude mice. MCF-7 MS cells formed tumors in mice administered $2 \times 10^{3}$ cells, whereas $2 \times 10^{5}$ parental $\mathrm{MCF}-7$ cells were required to generate tumors (Fig. 2A). With a given number of xenografted cells, MCF-7 MS cells generated tumors at a higher frequency in mouse xenografts than MCF-7 cells (Fig. 2A). Six weeks after inoculation of $2 \times 10^{6}$ cells, the average weight of MCF-7 MS cell-induced tumors $(0.98 \pm 0.25 \mathrm{~g})$ was significantly higher than that of MCF-7 cell-induced tumors $(0.66 \pm 0.11 \mathrm{~g})$ (Fig. 2B). The expression of OCT4 was also significantly higher in tumors transplanted with MCF-7 MS cells than in those transplanted with MCF-7 cells. These results showed that $\mathrm{MCF}-7 \mathrm{MS}$ cells had stronger tumorigenicity.

Taken together, our data showed that MCF-7 MS cells obtained from serum-free suspension culture possessed breast CSC-like properties such as self-renewal, differentiation potential, strong migration and invasion capacities, and high tumorigenicity.
Salinomycin inhibits proliferation, induces apoptosis, and reduces migration and invasion of MCF-7 MS cells. It is known that SAL can selectively kill BCSCs (16). To investigate whether SAL selectively killed CSC-like MCF-7 MS cells obtained from serum-free suspension culture, we tested the sensitivity of MCF-7 and MCF-7 MS cells to SAL. Cells were treated with various concentrations of SAL $(10-10,000 \mathrm{nM})$ for $48 \mathrm{~h}$, and cell viability was examined using CCK-8 assay. The survival rates of both cells decreased in a dose-dependent manner. The $\mathrm{IC}_{50}$ value for SAL in MCF-7 MS cells was $99 \mathrm{nM}$, which was $\sim 82$-fold lower than that in MCF-7 MS cells $(8,113 \mathrm{nM})$ (Fig. 3A), suggesting that SAL selectively killed MCF-7 MS cells. Furthermore, we examined the effect of SAL on mammosphere formation of MCF-7 MS cells. SAL (30 and $60 \mathrm{nM}$ ) significantly inhibited the primary and secondary mammosphere formation (Fig. 3B), further suggesting that SAL inhibited proliferation of MCF-7 MS cells.

We next examined the effect of SAL on the apoptosis of MCF-7 MS cells, using flow cytometry. SAL (30 and $60 \mathrm{nM}$ ) 


\begin{tabular}{|c|c|c|}
\hline \multicolumn{3}{|c|}{ Tumor incidence } \\
\hline $\begin{array}{c}\text { Cells } \\
\text { injected }\end{array}$ & MCF-7 & $\begin{array}{c}\text { MCF-7 } \\
\text { MS }\end{array}$ \\
\hline $2 \times 10^{3}$ & $0 / 6$ & $3 / 6$ \\
$2 \times 10^{4}$ & $0 / 6$ & $6 / 6$ \\
$2 \times 10^{5}$ & $2 / 6$ & $6 / 6$ \\
$2 \times 10^{6}$ & $5 / 6$ & $6 / 6$ \\
\hline
\end{tabular}
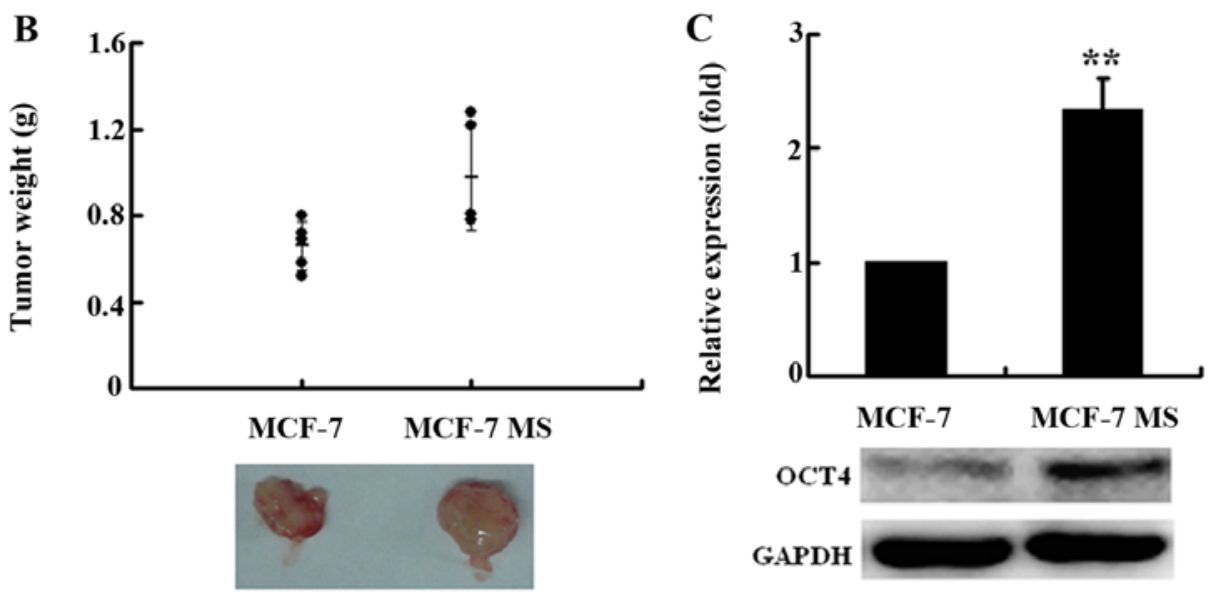

Figure 2. MCF-7 MS cells display high tumorigenicity. (A) Tumor incidence in mouse xenografts at 6 weeks after subcutaneous injection with the indicated number of MCF-7 and MCF-7 MS cells ( $\mathrm{n}=6$ per group). (B) The weight of tumors induced by inoculation with $2 \times 10^{6}$ MCF-7 or MCF-7 MS cells after mice were sacrificed at 6 weeks from cell inoculation. $n=5$. (C) Western blot analysis showing higher expression of OCT4 in tumors transplanted with MCF-7 MS cells than in those transplanted with MCF-7 cells. GAPDH is a loading control. The expression level of OCT4 was normalized to that of GAPDH. The OCT4/ GAPDH ratio in MCF-7 cells was set as 1 . Data are presented as mean \pm SD from there independent experiments. ${ }^{* *} \mathrm{P}<0.01$ vs. MCF-7 cells.

treatment for $48 \mathrm{~h}$ significantly increased the percentage of early apoptotic MCF-7 MS cells compared with the vehicle control (Fig. 3C). SAL treatment increased apoptosis of MCF-7 MS cells in a dose-dependent manner. However, compared with vehicle controls, SAL (30 and $60 \mathrm{nM}$ ) treatment for $48 \mathrm{~h}$ did not result in a significant change in the proportions of MCF-7 MS cells in G1, S, and G2 phases of the cell cycle (Fig. 3D).

We then investigated the effects of SAL on migration and invasion of MCF-7 MS cells using Transwell migration and invasion assays. Compared with vehicle controls, SAL (30 and $60 \mathrm{nM}$ ) treatment for $48 \mathrm{~h}$ resulted in a significantly lower number of MCF-7 MS cells that migrated into the lower chambers (Fig. 3E). SAL-induced inhibition of cell migration and invasion was dose-dependent.

The Hh signaling pathway is highly activated in MCF-7 MS cells and its activation can be effectively inhibited by salinomycin. The Hh signaling pathway regulates cell proliferation, apoptosis, and differentiation during normal development, and plays an important role in CSC maintenance and carcinogenesis $(6,8)$. Thus, we presumed that the Hh signaling pathway may be involved in SAL-induced cytotoxicity toward MCF-7 MS cells. We examined the protein expression of the main components of the Hh signaling pathway in MCF-7 and MCF-7 MS cells, including the Patched $(\mathrm{PTCH})$ receptor, Smoothened (SMO), Gli1, and Gli2. Western blot analysis showed that the expression levels of PTCH, SMO, Gli1, and Gli2 were significantly higher in MCF-7 MS cells than in MCF-7 cells (Fig. 4A), suggesting that the Hh signaling pathway was highly activated in MCF-7 MS cells. As expected, SAL (30 and $60 \mathrm{nM}$ ) effectively inhibited the expression of PTCH, SMO, Gli1, and Gli2 in MCF-7 MS cells dose-dependenly (Fig. 4B). Consistently with western blot results, immunofluorescence results showed that the expression of PTCH, SMO, Gli1, and Gli2 was substantially decreased in MCF-7 MS cells after the treatment of SAL (Fig. 4C). In addition, we examined the nuclear expression of Gli1, which more reliably reflects Hh signaling activation.
The nuclear expression of Gli1 was significantly inhibited by SAL treatment (Fig. 4D).

Oncogene C-myc, anti-apoptotic gene Bcl-2, cell cycle regulator cyclin D1, and transcription factor Snail are important downstream target genes of the Hh/Gli signaling pathway (33-36). To further demonstrate SAL-induced inhibition on $\mathrm{Hh}$ signaling activation, we investigated the effect of SAL on the protein expression of C-myc, Bcl-2, cyclin D1, and Snail. Western blot analysis showed that SAL (30 and $60 \mathrm{nM}$ ) significantly reduced the expression of C-myc, Bcl-2, and Snail, but not cyclin D1 (Fig. 5). The inhibitory effect of SAL on the expression of C-myc, Bcl-2, and Snail was dosedependent. These findings suggested that salinomycin could effectively inhibit the activation of Hh signaling pathway in MCF-7 MS cells.

Shh-mediated Hh signaling activation largely reverses SAL-induced cytotoxicity toward MCF-7 MS cells. To determine whether SAL-induced inhibition of the Hh signaling pathway is required for its selective cytotoxicity against MCF-7 MS cells, we conducted a series of rescue assays. Shh is a ligand that can activate the Hh signaling pathway (37), and therefore we used it for the rescue assays. As shown in Fig. 6A, Shh $(3 \mu \mathrm{g} / \mathrm{ml})$ significantly increased the expression of $\mathrm{PTCH}$, SMO, Gli1, and Gli2, indicating that Shh could activate the Hh signaling pathway in MCF-7 MS cells. As expected, Shh treatment could largely reverse SAL-induced inhibition on the expression of PTCH, SMO, Gli1, Gli2 (Fig. 6A) and downstream target genes, C-myc, Bcl-2, and Snail (Fig. 6B) in MCF-7 MS cells, suggesting that Shh prevented SAL-induced inhibition on Hh signaling activation.

We then investigated the effect of Shh on SAL-induced cytotoxicity in MCF-7 MS cells. Shh (3 $\mu \mathrm{g} / \mathrm{ml})$ significantly promoted cell viability of MCF-7 MS cells compared with the vehicle control (Fig. 6C). Moreover, Shh treatment could largely reverse SAL-induced decrease in cell viability of MCF-7 MS cells (Fig. 6C). In addition, we found that Shh $(3 \mu \mathrm{g} / \mathrm{ml})$ significantly promoted mammosphere formation and Shh 

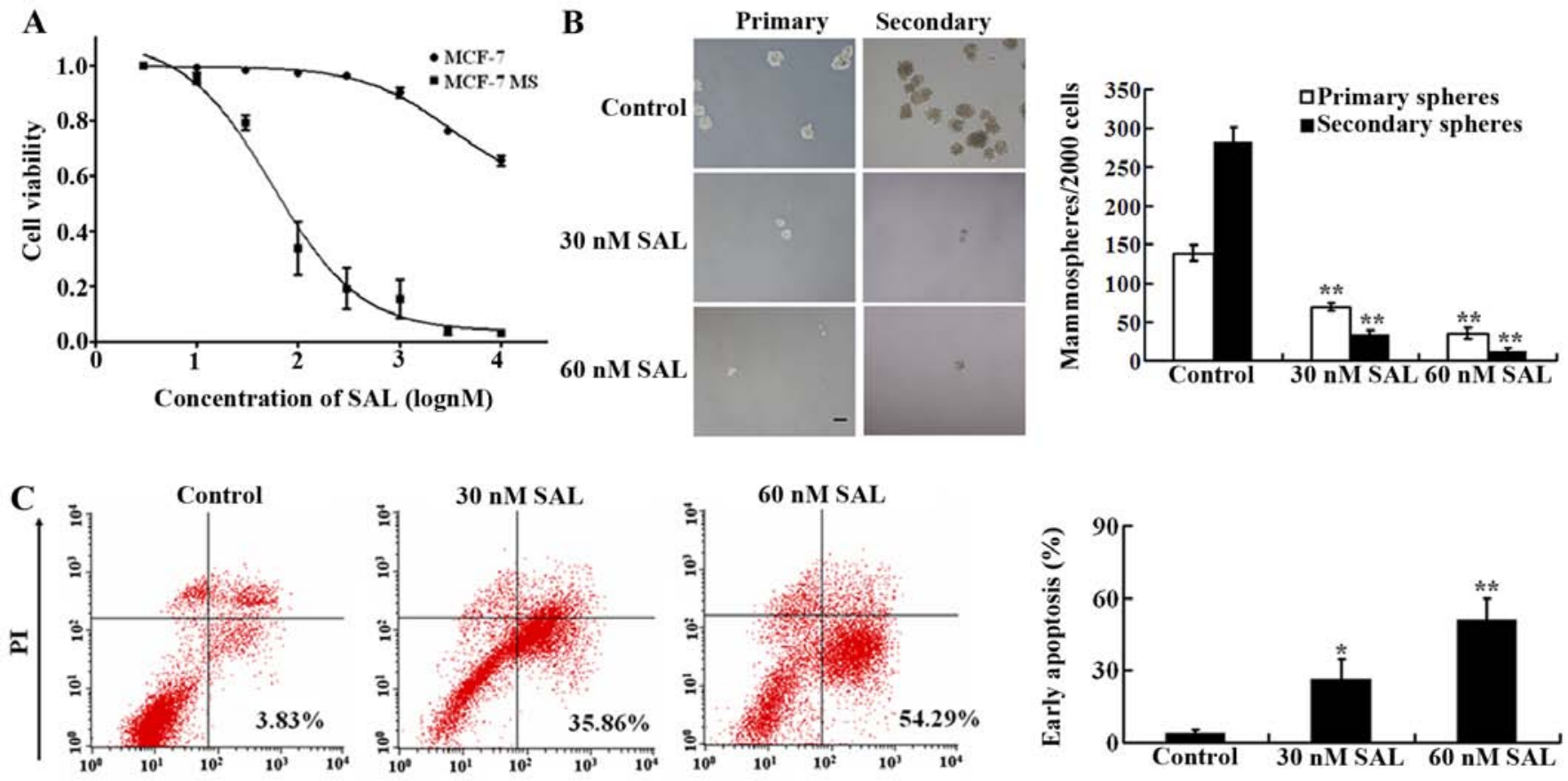

Annexin V-FITC

D

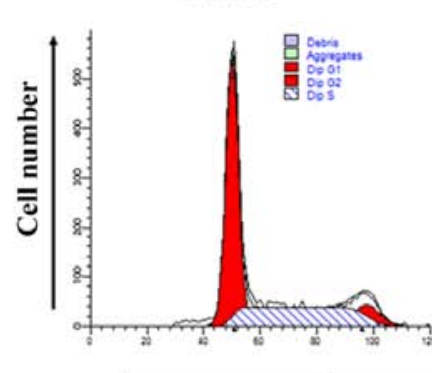

$30 \mathrm{nM}$ SAL

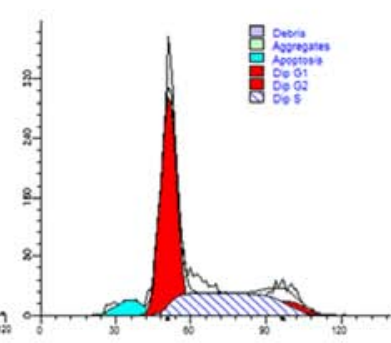

$60 \mathrm{nM} \mathrm{SAL}$
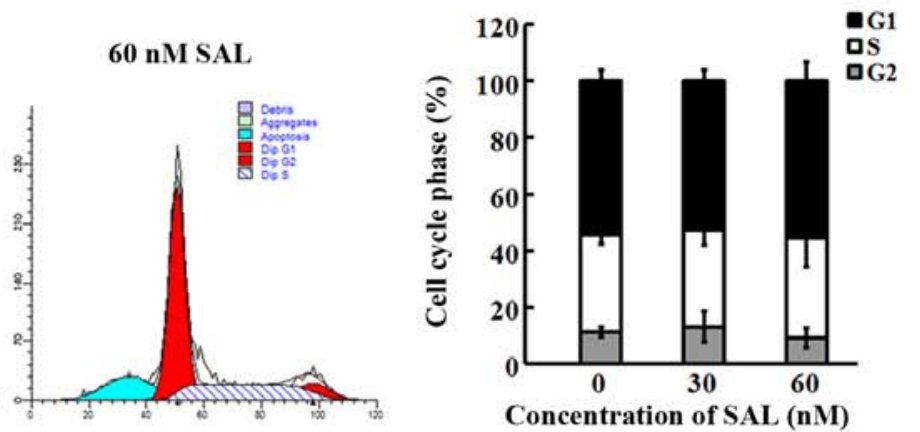

DNA content
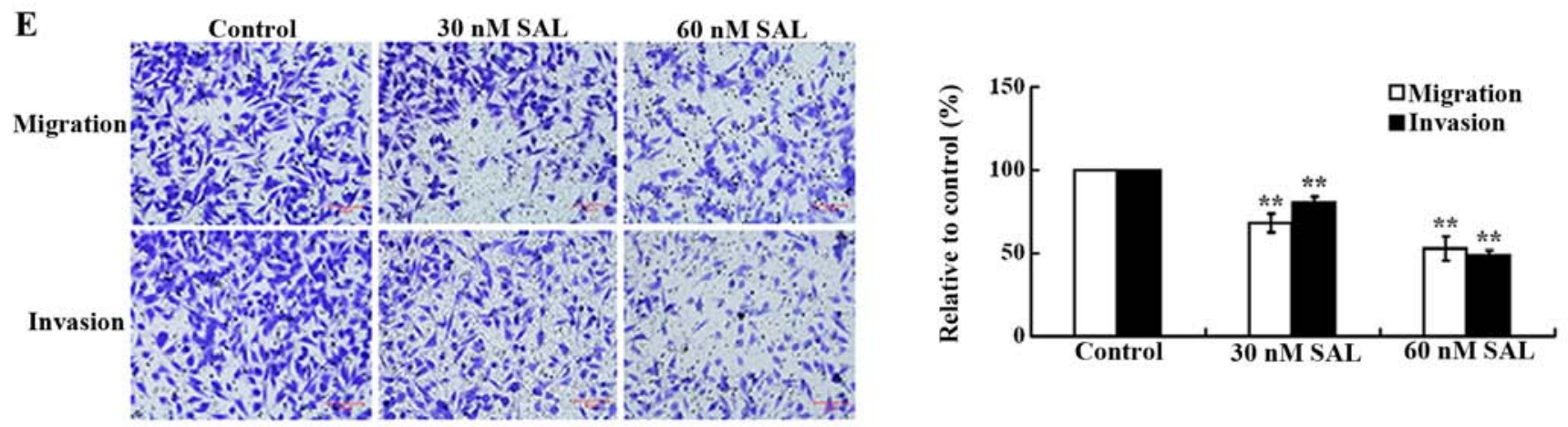

Figure 3. Salinomycin (SAL) inhibits proliferation, induces apoptosis, and reduces migration and invasion of MCF-7 MS cells. (A) The survival rate of MCF-7 and MCF-7 MS cells after treatment with different concentrations of SAL $(10-10,000 \mathrm{nM})$ for $48 \mathrm{~h}$. Cell viability was measured by CCK- 8 assay. $\mathrm{n}=3$ for each data point. (B) The primary and secondary mammosphere formation of MCF-7 MS cells after the treatment with 30 and $60 \mathrm{nM}$ SAL or DMSO as a control for $48 \mathrm{~h}$ (scale bar, $100 \mu \mathrm{m}$ ). (C) Flow cytometric analysis of apoptosis of MCF-7 MS cells stained with Annexin V and PI. MCF-7 MS cells were treated with 30 and $60 \mathrm{nM} \mathrm{SAL}$ or DMSO as a control for $48 \mathrm{~h}$. Cells in the lower right quadrant represent early apoptotic cells that are Annexin V-positive and PI-negative. (D) Flow cytometric analysis showing cell cycle distribution of MCF-7 MS cells stained with propidium iodide (PI). (E) Transwell migration and invasion assays showing SAL inhibited migration and invasion of MCF-7 MS cells. Cells that migrated or invaded into the lower Transwell chambers were counted (scale bar, $20 \mu \mathrm{m}$ ). The number of control cells migrating or invading to the lower chambers was set as $100 \%$. Data are presented as mean \pm SD from there independent experiments. ${ }^{*} \mathrm{P}<0.05,{ }^{* *} \mathrm{P}<0.01$ vs. control.

treatment could largely reverse SAL-induced inhibition on mammosphere formation (Fig. 6D). These results suggest that the Hh signaling pathway is critical for SAL-induced selective cytotoxicity against BCSC-enriched MCF-7 MS cells. 
A

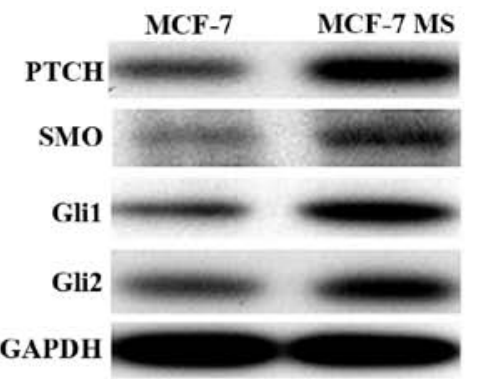

B

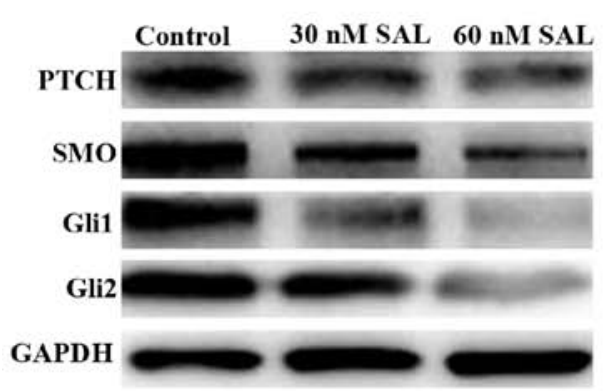

C
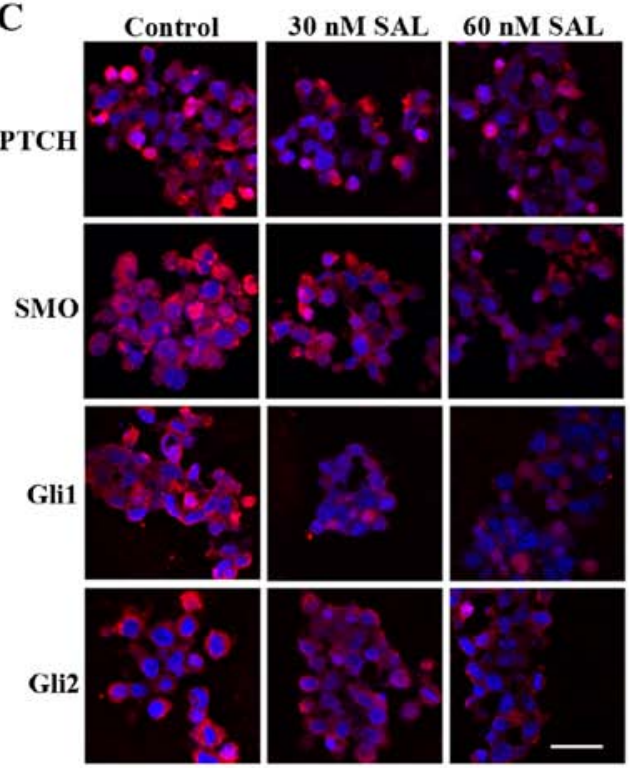
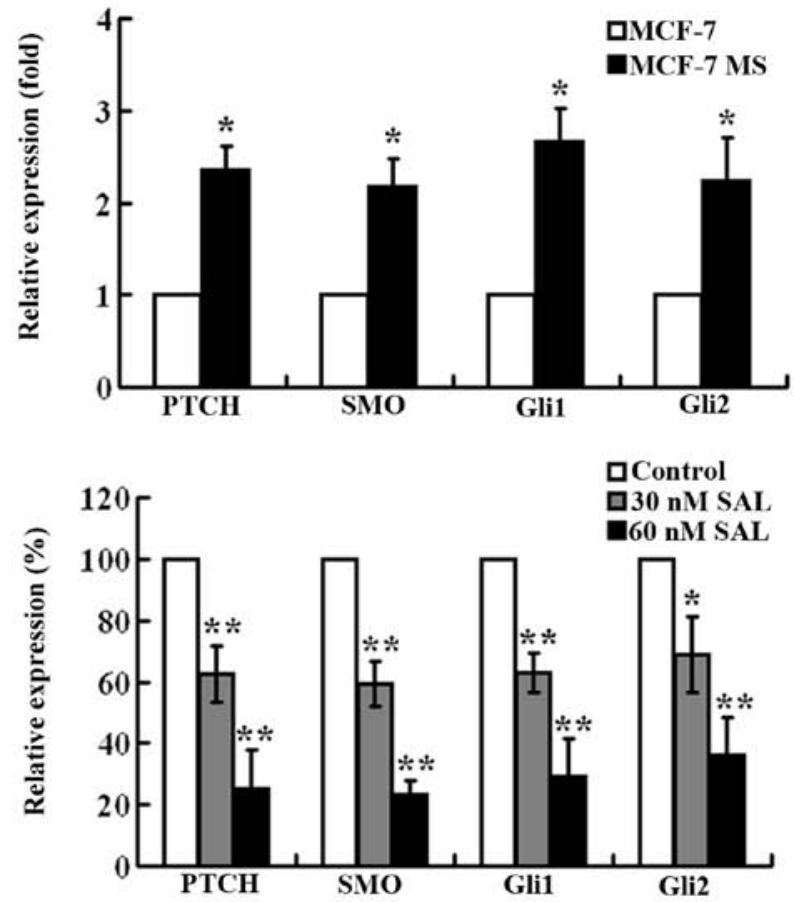

D
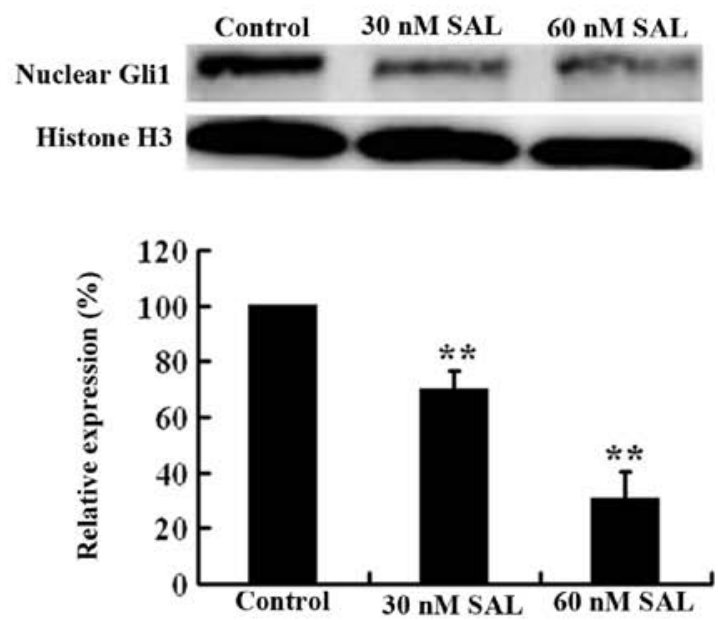

Figure 4. Salinomycin (SAL) inhibits Hh signaling activation in MCF-7 MS cells. (A) Western blot analysis showing the expression of PTCH, SMO, Gli1, and Gli2 in MCF-7 and MCF-7 MS cells. GAPDH is a loading control. The expression level of PTCH, SMO, Gli1, and Gli2 was normalized to that of GAPDH. The expression levels of these proteins in MCF-7 cells were set as 1. (B) Western blot analysis showing the expression of PTCH, SMO, Gli1, and Gli2 in MCF-7 MS cells treated with 30 and $60 \mathrm{nM}$ SAL or DMSO as a control for $48 \mathrm{~h}$. GAPDH was a loading control. The expression level of PTCH, SMO, Gli1, and Gli2 was normalized to that of GAPDH 1 . The expression levels of these proteins in control cells were set as $100 \%$. (C) Representative immunofluorescence images showing the expression of PTCH, SMO, Gli1 and Gli2 in MCF-7 MS cells treated with 30 and $60 \mathrm{nM} \mathrm{SAL}$ or DMSO as a control for $48 \mathrm{~h}$ (scale bar, $10 \mu \mathrm{m}$ ). (D) Western blot analysis showing the nuclear expression of Gli1 in MCF-7 MS cells treated with 30 and $60 \mathrm{nM} \mathrm{SAL}$ or DMSO as a control for $48 \mathrm{~h}$. Histone H3 is a loading control. The expression level of Gli1 was normalized to that of histone H3. The expression levels of Gli1 in control cells were set as $100 \%$. Data are presented as mean $\pm \mathrm{SD}$ from there independent experiments. ${ }^{*} \mathrm{P}<0.05,{ }^{* *} \mathrm{P}<0.01 \mathrm{vs}$. control.

\section{Discussion}

Recent studies proposed that CSCs are responsible for tumor chemoresistance, recurrence, and metastasis $(3,5,38)$. A subpopulation of breast cancer with the expression of the surface marker $\mathrm{CD} 44^{+} \mathrm{CD} 24^{- \text {/low }}$ has been shown to display stem cell-like properties with tumorigenic potential (32). However,
CSCs are rare, making them very difficult to isolate and study. Ponti et al have reported that $\mathrm{CD} 44^{+} \mathrm{CD} 24^{-/ \mathrm{low}}$ cells with stem cell-like properties are enriched in mammospheres obtained from culturing of breast cancer samples and breast cancer MCF-7 cells in suspension in serum-free medium (29). In the present study, we applied a similar procedure for culturing MCF-7 cells and obtained CD $44^{+} \mathrm{CD} 24^{- \text {llow }}$ cell-enriched 

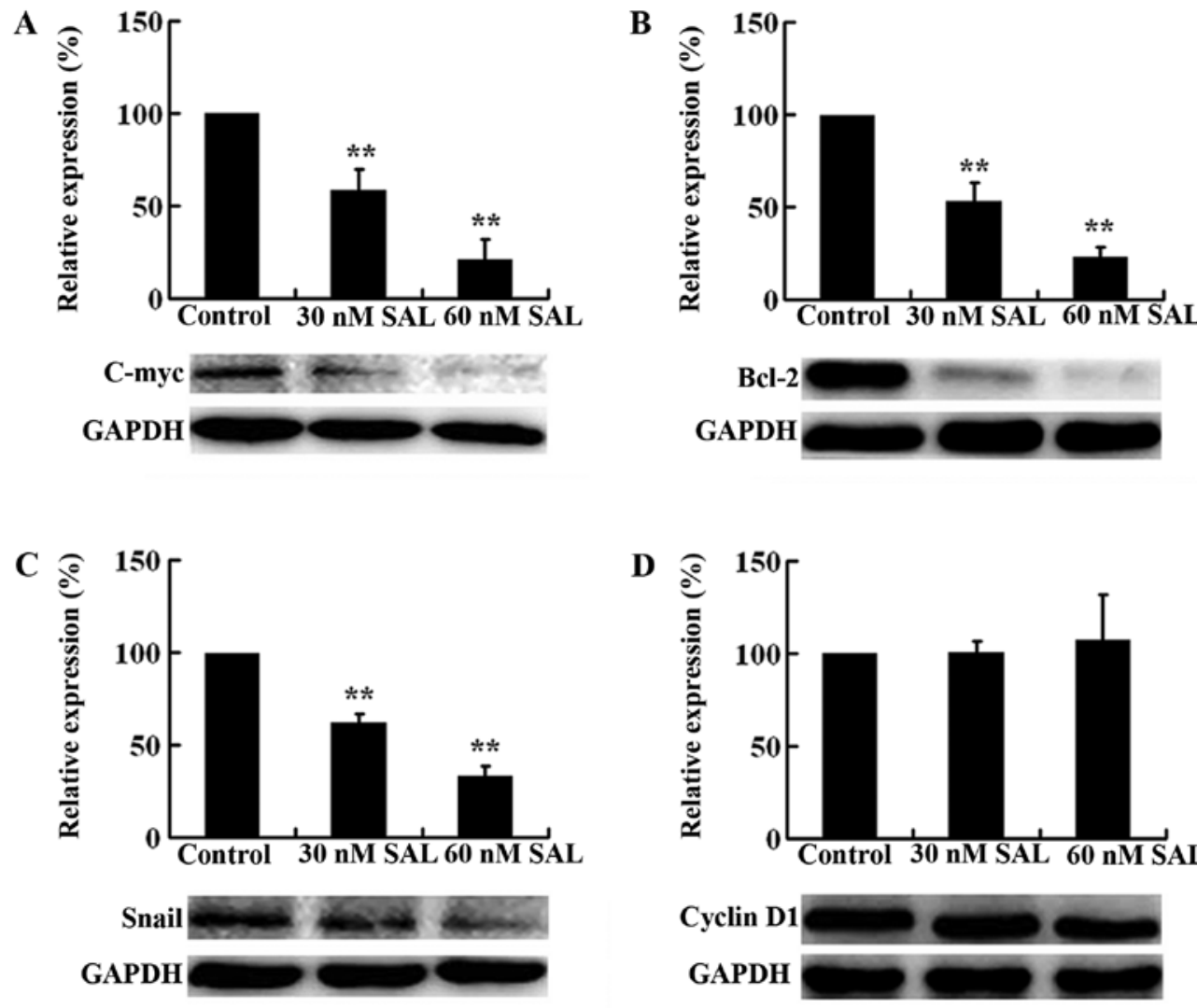

Figure 5. Salinomycin (SAL) inhibits the protein expression of the downstream target genes of the Hh/Gli signaling pathway. Western blot analysis showed the expression of (A) C-myc, (B) Bcl-2, (C) Snail, and (D) cyclin D1 in MCF-7 MS cells treated with 30 and $60 \mathrm{nM}$ SAL or DMSO as a control for $48 \mathrm{~h}$. GAPDH is a loading control. The expression level of C-myc, Bcl-2, Snail, and cyclin D1 was normalized to that of GAPDH. The expression levels of these proteins in control cells were set as $100 \%$. Data are presented as mean \pm SD from there independent experiments. ${ }^{* *} \mathrm{P}<0.01$ vs. control.

mammospheres. In addition, MCF-7 MS cells are featured with high expression of the stem cell marker OCT4, increased colony-forming ability, strong migration and invasion capabilities, re-differentiation potential, and strong tumorigenicity in vivo. These properties are typical characteristics of breast CSCs $(29,39,40)$.

Salinomycin (SAL) has been identified as a selective inhibitor of breast CSCs (16), and its selective inhibition on CSCs has also been observed in other cancers including colorectal cancer, gastric cancer, pancreatic cancer, head and neck squamous cell carcinoma (17-21). Here we showed that SAL exerted selective cytotoxicity to MCF-7 MS cells with an $\mathrm{IC}_{50}$ value of $99 \mathrm{nM}$, which was $\sim 82$-fold lower compared with parental MCF-7 cells, suggesting that SAL selectively killed MCF-7 MS cells. In addition, Dong et al found that SAL selectively targeted $\mathrm{CD} 133^{+}$cell subpopulations and reduced cell migration in colorectal cancer cells (17). In the present study, we found that SAL reduced migration and invasion of MCF-7 MS cells. These studies suggest that SAL may prevent cancer metastasis. Additionally, SAL selectively induces cell apoptosis in chronic lymphocytic leukemia cells (27). Similarly, we found that SAL induced apoptosis in MCF-7 MS cells.

The mechanisms underlying SAL-induced cytotoxicity to CSCs remain unclear. Lu et al reported that SAL inhibited the Wnt signaling pathway in chronic lymphocytic leukemia cells (27). In addition, SAL has been found to inhibit CSCs in osteosarcoma and endometrial cancer and downregulate Wnt signaling $(21,28)$. It is well known that similar to the Wnt signaling pathway, the Hh signaling pathway plays an important role in maintaining self-renewal of stem cells $(37,41)$. The Hh signaling pathway is activated by binding of ligands to the PTCH receptor and subsequently alleviating inhibition of SMO, thus regulating the expression of Gli transcription factors (33-36). It has been reported that the expression of PTCH, SMO, Gli1 and Gli2 are upregulated in breast CSCs (37). In the present study, we found that the expression of PTCH, SMO, Gli1, and Gli2 was significantly higher in MCF-7 MS cells, T47D MS cells and MCF-7 MS xenograft tumors, suggesting that the Hh signaling pathway is activated in breast CSCs. In addition, we found that SAL inhibited $\mathrm{Hh}$ signaling activation, and $\mathrm{Hh}$ signaling activation reduced SAL-induced cytotoxicity in MCF-7 MS cells, suggesting that the Hh signaling pathway is involved in SAL-induced cytotoxicity to breast CSCs. Tanaka et al reported that inhibition of the Hh signaling pathway decreased proliferation of $\mathrm{CD} 44^{+} \mathrm{CD} 24^{- \text {llow }}$ breast cancer cells (14), suggesting that the Hh signaling pathway plays an important role in maintaining proliferation of breast CSCs. In agreement with their findings, we found that SAL inhibited Hh signaling activation, and decreased $\mathrm{CD} 44^{+} \mathrm{CD} 24^{-/ \text {low }}$ cell-enriched mammosphere formation, suggesting that SAL reduces proliferation of breast CSCs via inhibition of the Hh signaling pathway. Recently, Lu et al reported that salinomycin exerted anticancer effects 
A Shh $(3 \mu \mathrm{g} / \mathrm{ml})$ ' SAL (60 nM)

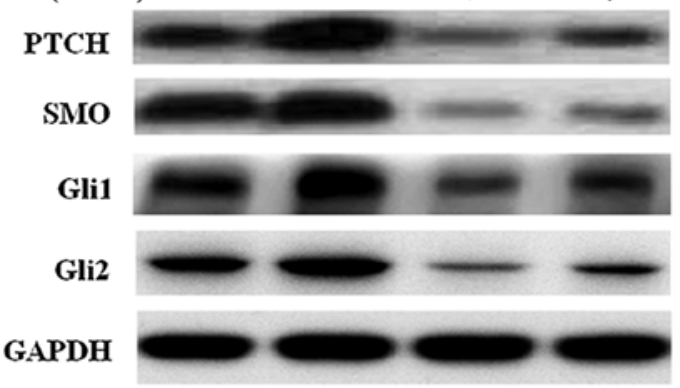

B

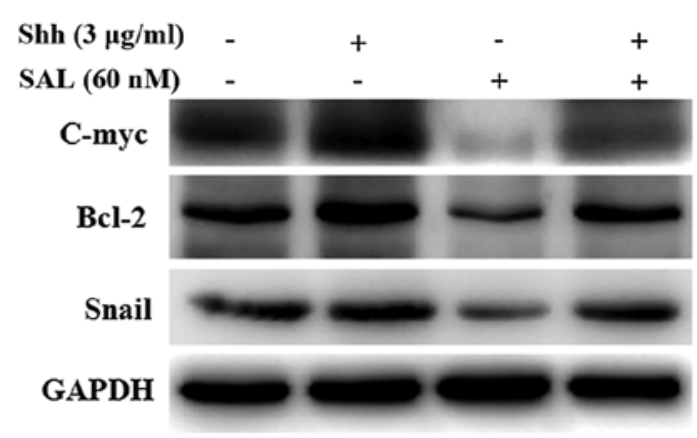

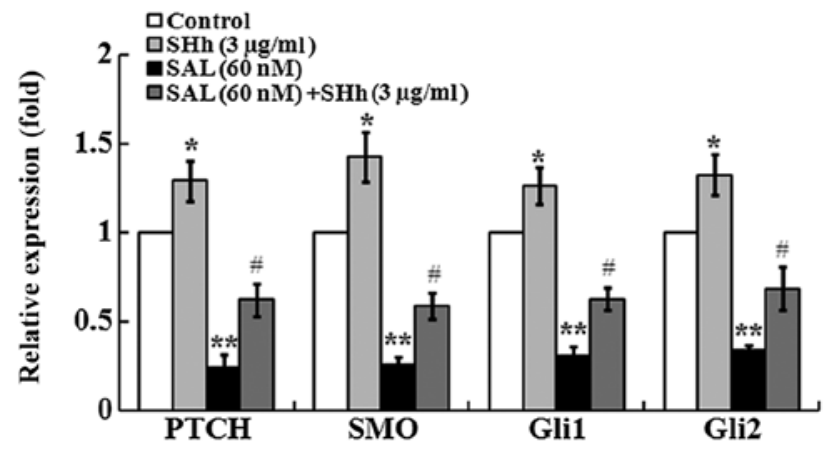

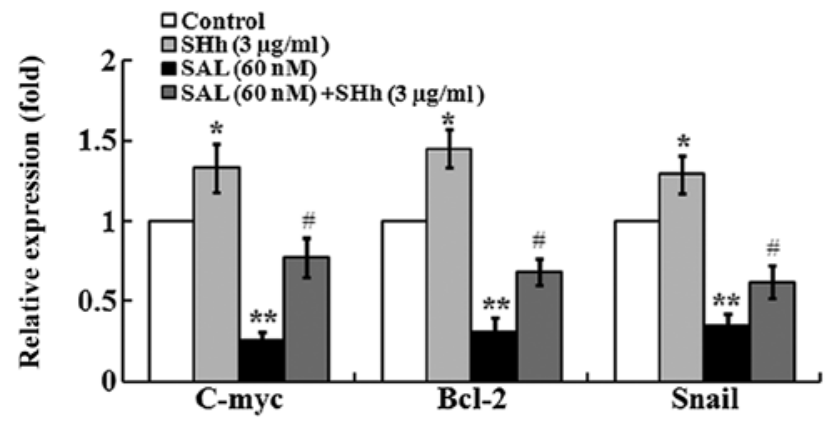

C

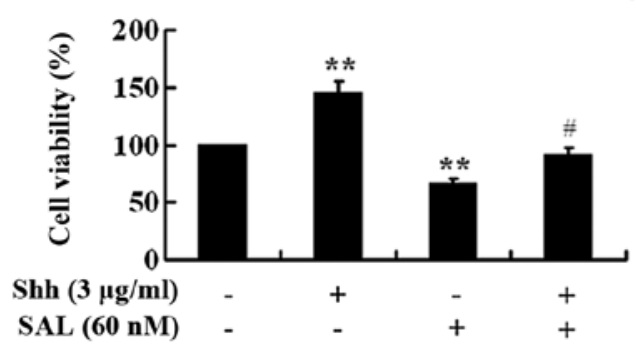

D

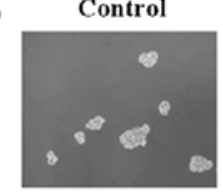

SAL

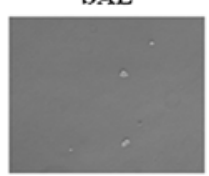

Shh

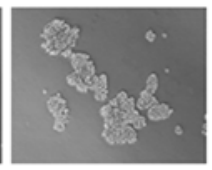

Shh + SAL

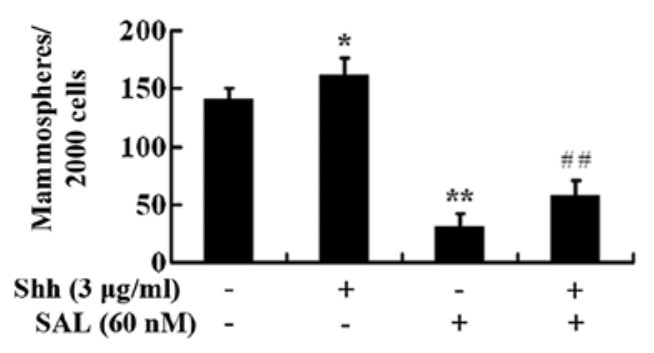

Figure 6. Hh signaling activation decreases SAL-induced cytotoxicity in MCF-7 MS cells. (A) Western blot analysis showing the expression of PTCH, SMO, Gli1, and Gli2 in MCF-7 MS cells treated with SAL $(60 \mathrm{nM})$, Shh $(3 \mu \mathrm{g} / \mathrm{ml})$, SAL $(60 \mathrm{nM})+$ Shh $(3 \mu \mathrm{g} / \mathrm{ml})$, or DMSO as a control for $48 \mathrm{~h}$. GAPDH is a loading control. The expression level of PTCH, SMO, Gli1, and Gli2 was normalized to that of GAPDH. The expression levels of these proteins in control cells were set as 1. (B) Western blot analysis showing the expression of C-myc, Bcl-2, and Snail in MCF-7 MS cells treated with SAL (60 nM), Shh (3 $\mu \mathrm{g} / \mathrm{ml})$, SAL $(60 \mathrm{nM})+\operatorname{Shh}(3 \mu \mathrm{g} / \mathrm{ml})$, or DMSO as a control for $48 \mathrm{~h}$. GAPDH is a loading control. The expression level of C-myc, Bcl-2, and Snail was normalized to that of GAPDH. The expression levels of these proteins in control cells were set as 1. (C) Cell viability of MCF-7 MS cells after treatment with SAL (60 nM), Shh $(3 \mu \mathrm{g} / \mathrm{ml})$, SAL $(60 \mathrm{nM})+\operatorname{Shh}(3 \mu \mathrm{g} / \mathrm{ml})$, or DMSO as a control for $48 \mathrm{~h}$ was measured by CCK-8 assay. (D) Mammosphere formation assay of MCF-7 MS cells after treatment with SAL $(60 \mathrm{nM})$, Shh $(3 \mu \mathrm{g} / \mathrm{ml})$, SAL $(60 \mathrm{nM})+$ Shh $(3 \mu \mathrm{g} / \mathrm{ml})$, or DMSO as a control for $48 \mathrm{~h}$ (scale bar, $100 \mu \mathrm{m})$. Data are presented as mean $\pm \mathrm{SD}$ from there independent experiments. ${ }^{*} \mathrm{P}<0.05,{ }^{* *} \mathrm{P}<0.01$ vs. control. ${ }^{\#} \mathrm{P}<0.05,{ }^{\# /} \mathrm{P}<0.01$ vs. SAL alone.

on MCF-7 cells via modulation of Hedgehog signaling (42). However, their study focused on the anticancer effects of salinomycin on MCF-7 cells, not breast cancer stem cells. While in the present study we demonstrated that salinomycin selectively induced cytotoxicity to BCSC-enriched MCF-7 mammosphere cells through targeting the Hedgehog signaling pathway.

$\mathrm{Hh} / \mathrm{Gli}$ signaling activation results in an increase in the expression of many downstream target genes including C-myc, Bcl-2, cyclin D1, and Snail, which regulate cell proliferation, apoptosis, cell cycle, migration, and epithelialmesenchymal transition (EMT) (33-36). It has been reported that C-myc is required for proliferation and self-renewal of normal stem cell and CSCs $(43,44)$. Our findings that SAL significantly inhibited cell proliferation and reduced the expression of C-myc in MCF-7 MS cells suggest that SAL may inhibit breast CSC proliferation via the downregulation of C-myc. In addition, we also found that SAL induced cell apoptosis and downregulated the expression of anti-apoptotic Bcl-2 proteins in MCF-7 MS cells, suggesting that SAL may induce breast CSC apoptosis via the downregulation of Bcl-2. Consistently with our findings, $\mathrm{Fu}$ et al found that inhibition of Bcl-2 expression promoted pancreatic CSC apoptosis (45). Furthermore, we found that SAL inhibited cell migration and invasion in MCF-7 MS cells and reduced the expression of Snail, a transcription factor that regulates EMT $(46,47)$. It has been reported that blockade of Hh signaling downregulates the expression of Snail, and inhibits pancreatic cancer 
invasion and metastases (48). Therefore, SAL may inhibit breast CSC migration and invasion by inhibiting the expression of Snail. Taken together, these results suggests that SAL may produce cytotoxicity to MCF-7 MS cells via repressing the $\mathrm{Hh} / \mathrm{Gli}$ signaling pathway by inhibiting $\mathrm{C}$-myc expression to reduce cell proliferation, inhibiting $\mathrm{Bcl}-2$ expression to promote cell apoptosis, and inhibiting Snail expression to reduce cell migration and invasion.

Cell cycle regulator cyclin D1 is one of the downstream target genes of the Hh signaling pathway (35). However, in the present study, although SAL inhibited Hh signaling activation in MCF-7 MS cells, SAL did not alter the expression of cell cycle regulator cyclin D1, and did not cause cell cycle arrest measured by flow cytometry. Similarly, SAL-induced apoptosis is not accompanied by cell cycle arrest in human Molt-4 leukemia cells (49). In contrast, it has been reported that SAL downregulates the expression of cyclin D1 in ovarian cancer and endometrial cancer cells, and induces apoptosis via cell cycle arrest at G1 in ovarian cancer cells (50). The effect of SAL on cell cycle regulation seems to be cell-context dependent.

In summary, we found that SAL exerted cytotoxicity to MCF-7 MS cells by inhibiting proliferation, inducing apoptosis, and reducing migration and invasion, but not affecting the cell cycle. SAL-induced cytotoxicity was associated with inhibition of $\mathrm{Hh}$ signaling activation and the expression of downstream target genes including C-myc, Bcl-2 and Snail, but not cyclin D1. Therefore, our studies not only revealed a novel molecular mechanism underlying SAL-induced selective cytotoxicity to BCSCs, but also suggest that the Hh signaling pathway likely plays an important role in the maintenance of CSC properties of breast cancer cells, and this pathway is a possible drug target for the treatment of breast cancer.

\section{Acknowledgements}

The present study was supported by grants from the National Natural Science Foundation of China (grant nos. 81373427 and 31300693), Program for Liaoning Innovative Research Team in University (grant no. LT2014016), Program for Liaoning Excellent Talents in University (grant no. LJQ2014084), the Natural Science Foundation of Liaoning Province (grant no. 2014021085) and the S\&T Projects in Shenyang, China (grant no. F14-232-6-05).

\section{References}

1. DeSantis C, Siegel R, Bandi P and Jemal A: Breast cancer statistics, 2011. CA Cancer J Clin 61: 409-418, 2011.

2. Marquette $\mathrm{C}$ and Nabell L: Chemotherapy-resistant metastatic breast cancer. Curr Treat Options Oncol 13: 263-275, 2012.

3. Zhou J, Zhang H, Gu P, Bai J, Margolick JB and Zhang Y: NF-kappaB pathway inhibitors preferentially inhibit breast cancer stem-like cells. Breast Cancer Res Treat 111: 419-427, 2008.

4. Diehn M, Cho RW, Lobo NA, Kalisky T, Dorie MJ, Kulp AN, Qian D, Lam JS, Ailles LE, Wong M, et al: Association of reactive oxygen species levels and radioresistance in cancer stem cells. Nature 458: 780-783, 2009.

5. Sampieri K and Fodde R: Cancer stem cells and metastasis. Semin Cancer Biol 22: 187-193, 2012.

6. Varjosalo $M$ and Taipale J: Hedgehog: Functions and mechanisms. Genes Dev 22: 2454-2472, 2008.
7. Dontu G, Jackson KW, McNicholas E, Kawamura MJ, Abdallah WM and Wicha MS: Role of Notch signaling in cell-fate determination of human mammary stem/progenitor cells. Breast Cancer Res 6: R605-R615, 2004.

8. Taipale $\mathbf{J}$ and Beachy PA: The Hedgehog and Wnt signalling pathways in cancer. Nature 411: 349-354, 2001.

9. Watkins DN, Berman DM, Burkholder SG, Wang B, Beachy PA and Baylin SB: Hedgehog signalling within airway epithelial progenitors and in small-cell lung cancer. Nature 422: 313-317, 2003.

10. Ma X, Sheng T, Zhang Y, Zhang X, He J, Huang S, Chen K, Sultz J, Adegboyega PA, Zhang H, et al: Hedgehog signaling is activated in subsets of esophageal cancers. Int J Cancer 118: 139-148, 2006

11. Fukaya M, Isohata N, Ohta H, Aoyagi K, Ochiya T, Saeki N, Yanagihara K, Nakanishi Y, Taniguchi $\mathrm{H}$, Sakamoto $\mathrm{H}$, et al: Hedgehog signal activation in gastric pit cell and in diffuse-type gastric cancer. Gastroenterology 131: 14-29, 2006.

12. Kayed H, Kleeff J, Keleg S, Guo J, Ketterer K, Berberat PO, Giese N, Esposito I, Giese T, Büchler MW, et al: Indian hedgehog signaling pathway: Expression and regulation in pancreatic cancer. Int J Cancer 110: 668-676, 2004.

13. Clement V, Sanchez P, de Tribolet N, Radovanovic I and Ruiz i Altaba A: HEDGEHOG-GLI1 signaling regulates human glioma growth, cancer stem cell self-renewal, and tumorigenicity. Curr Biol 17: 165-172, 2007.

14. Tanaka H, Nakamura M, Kameda C, Kubo M, Sato N, Kuroki S, Tanaka M and Katano M: The Hedgehog signaling pathway plays an essential role in maintaining the $\mathrm{CD} 44^{+} \mathrm{CD} 24^{-/ \text {low }}$ subpopulation and the side population of breast cancer cells. Anticancer Res 29: 2147-2157, 2009.

15. Sheikh A, Alvi AA, Aslam HM and Haseeb A: Hedgehog pathway inhibitors - current status and future prospects. Infect Agent Cancer 7: 29, 2012.

16. Gupta PB, Onder TT, Jiang G, Tao K, Kuperwasser C, Weinberg RA and Lander ES: Identification of selective inhibitors of cancer stem cells by high-throughput screening. Cell 138: 645-659, 2009.

17. Dong TT, Zhou HM, Wang LL, Feng B, Lv B and Zheng MH: Salinomycin selectively targets ' $\mathrm{CD} 133^{+}$' cell subpopulations and decreases malignant traits in colorectal cancer lines. Ann Surg Oncol 18: 1797-1804, 2011.

18. Zhi QM, Chen XH, Ji J, Zhang JN, Li JF, Cai Q, Liu BY, Gu QL, Zhu ZG and Yu YY: Salinomycin can effectively kill ALDH(high) stem-like cells on gastric cancer. Biomed Pharmacother 65: 509-515, 2011.

19. Zhang GN, Liang Y, Zhou LJ, Chen SP, Chen G, Zhang TP, Kang T and Zhao YP: Combination of salinomycin and gemcitabine eliminates pancreatic cancer cells. Cancer Lett 313: 137-144, 2011.

20. Kuo SZ, Blair KJ, Rahimy E, Kiang A, Abhold E, Fan JB, Wang-Rodriguez J, Altuna $X$ and Ongkeko WM: Salinomycin induces cell death and differentiation in head and neck squamous cell carcinoma stem cells despite activation of epithelial-mesenchymal transition and Akt. BMC Cancer 12: 556, 2012.

21. Kusunoki S, Kato K, Tabu K, Inagaki T, Okabe H, Kaneda H, Suga S, Terao Y, Taga T and Takeda S: The inhibitory effect of salinomycin on the proliferation, migration and invasion of human endometrial cancer stem-like cells. Gynecol Oncol 129: 598-605, 2013.

22. Ketola K, Hilvo M, Hyötyläinen T, Vuoristo A, Ruskeepää AL, Orešič M, Kallioniemi $\mathrm{O}$ and Iljin K: Salinomycin inhibits prostate cancer growth and migration via induction of oxidative stress. Br J Cancer 106: 99-106, 2012.

23. Kim KY, Yu SN, Lee SY, Chun SS, Choi YL, Park YM, Song CS, Chatterjee B and Ahn SC: Salinomycin-induced apoptosis of human prostate cancer cells due to accumulated reactive oxygen species and mitochondrial membrane depolarization. Biochem Biophys Res Commun 413: 80-86, 2011.

24. Lieke T, Ramackers W, Bergmann S, Klempnauer J, Winkler M and Klose J: Impact of salinomycin on human cholangiocarcinoma: Induction of apoptosis and impairment of tumor cell proliferation in vitro. BMC Cancer 12: 466, 2012.

25. Wang F, He L, Dai WQ, Xu YP, Wu D, Lin CL, Wu SM, Cheng P, Zhang Y, Shen M, et al: Salinomycin inhibits proliferation and induces apoptosis of human hepatocellular carcinoma cells in vitro and in vivo. PLoS One 7: e50638, 2012.

26. Verdoodt B, Vogt M, Schmitz I, Liffers ST, Tannapfel A and Mirmohammadsadegh A: Salinomycin induces autophagy in colon and breast cancer cells with concomitant generation of reactive oxygen species. PLoS One 7: e44132, 2012. 
27. Lu D, Choi MY, Yu J, Castro JE, Kipps TJ and Carson DA: Salinomycin inhibits Wnt signaling and selectively induces apoptosis in chronic lymphocytic leukemia cells. Proc Natl Acad Sci USA 108: 13253-13257, 2011.

28. Tang QL, Zhao ZQ, Li JC, Liang Y, Yin JQ, Zou CY, Xie XB, Zeng YX, Shen JN, Kang T, et al: Salinomycin inhibits osteosarcoma by targeting its tumor stem cells. Cancer Lett 311: 113-121, 2011.

29. Ponti D, Costa A, Zaffaroni N, Pratesi G, Petrangolini G, Coradini D, Pilotti S, Pierotti MA and Daidone MG: Isolation and in vitro propagation of tumorigenic breast cancer cells with stem/progenitor cell properties. Cancer Res 65: 5506-5511, 2005.

30. Fan X, Chen X, Deng W, Zhong G, Cai Q and Lin T: Up-regulated microRNA-143 in cancer stem cells differentiation promotes prostate cancer cells metastasis by modulating FNDC3B expression. BMC Cancer 13: 61, 2013.

31. He M, Sun HG, Hao JY, Li YL, Yu JK, Yan YY, Zhao L, Li N, Wang Y, Bai XF, et al: RNA interference-mediated FANCF silencing sensitizes OVCAR3 ovarian cancer cells to adriamycin through increased adriamycin-induced apoptosis dependent on JNK activation. Oncol Rep 29: 1721-1729, 2013.

32. Al-Hajj M, Wicha MS, Benito-Hernandez A, Morrison SJ and Clarke MF: Prospective identification of tumorigenic breast cancer cells. Proc Natl Acad Sci USA 100: 3983-3988, 2003.

33. Hatton BA, Knoepfler PS, Kenney AM, Rowitch DH, de Alborán IM, Olson JM and Eisenman RN: N-myc is an essential downstream effector of Shh signaling during both normal and neoplastic cerebellar growth. Cancer Res 66: 8655-8661, 2006.

34. Bigelow RL, Chari NS, Unden AB, Spurgers KB, Lee S, Roop DR, Toftgard R and McDonnell TJ: Transcriptional regulation of bcl-2 mediated by the sonic hedgehog signaling pathway through gli-1. J Biol Chem 279: 1197-1205, 2004.

35. Duman-Scheel M, Weng L, Xin S and Du W: Hedgehog regulates cell growth and proliferation by inducing cyclin D and cyclin $\mathrm{E}$. Nature 417: 299-304, 2002.

36. Li X, Deng W, Nail CD, Bailey SK, Kraus MH, Ruppert JM and Lobo-Ruppert SM: Snail induction is an early response to Gli1 that determines the efficiency of epithelial transformation. Oncogene 25: 609-621, 2006.

37. Liu S, Dontu G, Mantle ID, Patel S, Ahn NS, Jackson KW, Suri $\mathrm{P}$ and Wicha MS: Hedgehog signaling and Bmi-1 regulate self-renewal of normal and malignant human mammary stem cells. Cancer Res 66: 6063-6071, 2006.

38. Liu H, Patel MR, Prescher JA, Patsialou A, Qian D, Lin J, Wen S, Chang YF, Bachmann MH, Shimono Y, et al: Cancer stem cells from human breast tumors are involved in spontaneous metastases in orthotopic mouse models. Proc Natl Acad Sci USA 107: 18115-18120,2010.
39. Cariati M, Naderi A, Brown JP, Smalley MJ, Pinder SE, Caldas C and Purushotham AD: Alpha-6 integrin is necessary for the tumourigenicity of a stem cell-like subpopulation within the MCF7 breast cancer cell line. Int J Cancer 122: 298-304, 2008.

40. Zhao XQ, Dai CL, Ohnuma S, Liang YJ, Deng W, Chen JJ, Zeng MS, Ambudkar SV, Chen ZS and Fu LW: Tandutinib (MLN518/CT53518) targeted to stem-like cells by inhibiting the function of ATP-binding cassette subfamily G member 2. Eur J Pharm Sci 49: 441-450, 2013.

41. Takashima S, Mkrtchyan M, Younossi-Hartenstein A, Merriam JR and Hartenstein V: The behaviour of Drosophila adult hindgut stem cells is controlled by Wnt and Hh signalling. Nature 454: 651-655, 2008.

42. Lu Y, Ma W, Mao J, Yu X, Hou Z, Fan S, Song B, Wang H, Li J, Kang L, et al: Salinomycin exerts anticancer effects on human breast carcinoma MCF-7 cancer stem cells via modulation of Hedgehog signaling. Chem Biol Interact 228: 100-107, 2015.

43. Wang J, Wang $\mathrm{H}$, Li Z, Wu Q, Lathia JD, McLendon RE, Hjelmeland $\mathrm{AB}$ and Rich JN: c-Myc is required for maintenance of glioma cancer stem cells. PLoS One 3: e3769, 2008.

44. Murphy MJ, Wilson A and Trumpp A: More than just proliferation: Myc function in stem cells. Trends Cell Biol 15: 128-137, 2005.

45. Fu J, Rodova M, Roy SK, Sharma J, Singh KP, Srivastava RK and Shankar S: GANT-61 inhibits pancreatic cancer stem cell growth in vitro and in NOD/SCID/IL2R gamma null mice xenograft. Cancer Lett 330: 22-32, 2013

46. Kalluri R and Weinberg RA: The basics of epithelial-mesenchymal transition. J Clin Invest 119: 1420-1428, 2009.

47. Haslehurst AM, Koti M, Dharsee M, Nuin P, Evans K, Geraci J, Childs T, Chen J, Li J, Weberpals J, et al: EMT transcription factors snail and slug directly contribute to cisplatin resistance in ovarian cancer. BMC Cancer 12: 91, 2012.

48. Feldmann G, Dhara S, Fendrich V, Bedja D, Beaty R, Mullendore M, Karikari C, Alvarez H, Iacobuzio-Donahue C, Jimeno A, et al: Blockade of hedgehog signaling inhibits pancreatic cancer invasion and metastases: A new paradigm for combination therapy in solid cancers. Cancer Res 67: 2187-2196, 2007.

49. Fuchs D, Heinold A, Opelz G, Daniel V and Naujokat C: Salinomycin induces apoptosis and overcomes apoptosis resistance in human cancer cells. Biochem Biophys Res Commun 390: 743-749, 2009.

50. Koo KH, Kim H, Bae YK, Kim K, Park BK, Lee CH and Kim YN: Salinomycin induces cell death via inactivation of Stat3 and downregulation of Skp2. Cell Death Dis 4: e693, 2013. 